\title{
Decorated Caddoan Ceramics from Two Sites on the Elm Fork of the Trinity River, Dallas County, Texas
}

Timothy K. Perttula

Heritage Research Center, Stephen F. Austin State University

Follow this and additional works at: https://scholarworks.sfasu.edu/ita

Part of the American Material Culture Commons, Archaeological Anthropology Commons, Environmental Studies Commons, Other American Studies Commons, Other Arts and Humanities Commons, Other History of Art, Architecture, and Archaeology Commons, and the United States History Commons

Tell us how this article helped you.

This Article is brought to you for free and open access by the Center for Regional Heritage Research at SFA ScholarWorks. It has been accepted for inclusion in Index of Texas Archaeology: Open Access Gray Literature from the Lone Star State by an authorized editor of SFA ScholarWorks. For more information, please contact cdsscholarworks@sfasu.edu. 
Decorated Caddoan Ceramics from Two Sites on the Elm Fork of the Trinity River, Dallas County, Texas

\section{Creative Commons License}

(c) (1) (8)

This work is licensed under a Creative Commons Attribution-NonCommercial 4.0 International License 


\title{
DECORATED CADDOAN CERAMICS FROM TWO SITES ON THE ELM FORK OF THE TRINITY RIVER, DALLAS COUNTY, TEXAS
}

\author{
Timothy K. Perttula
}

\section{Introduction}

Caddoan pottery is widely distributed as items of trade and exchange across the northern and eastern parts of the state of Texas (and indeed in several other states outside Texas), although specific information on the amounts and/or kinds of Caddoan pottery actually recovered in such non-Caddoan archaeological contexts is still quite spotty (Perttula et al. 1995:189-190). Over the last several years, I have been compiling this ceramic information where it is available (i.e., in the published literature, from unpublished papers, and in the collections of avocational archaeologists) as part of a broader study of prehistoric Caddoan interaction and trade with neighboring groups. In this paper, I document small but interesting samples of decorated Caddoan ceramics from 41DL239 and 41DL240 on the Elm Fork of the Trinity River in Dallas County, Texas.

\section{The Sites}

Both 41DL239 and 41DL240 are situated on alluvial terraces of the Elm Fork of the Trinity River in the northwestern part of Dallas County, Texas (Lorrain 1985; Prikryl 1990). Site 41 DL239 has received surface collections by private individuals and the Dallas Archeological Society (Lorrain 1978), while limited test excavations were conducted in the early 1980s at 41DL240 (Lorrain 1980).

Both sites are multi-component, with Archaic and Late Prehistoric occupations discerned from projectile points collected from the surface and/or the test excavations (Prikryl 1990:93). Late Prehistoric artifacts at 41DL239 include one Steiner arrowpoint, an untyped stemmed arrowpoint, one possible Perdiz arrowpoint, a Harrell arrowpoint, and nine sherds of Caddoan ceramics (Prikryl [1990:93] notes eight sherds from the site). At 41DL240, the Late Prehistoric materials reported by Lorrain (1985) consist of four stemmed and serrated arrowpoints (of the Steiner type according to Prikryl [1990:93]) and 34 Caddoan pottery sherds (Prikryl [1990:93] notes only 27 sherds from 41DL240), 25 of which are part of one vessel (Lorrain 1985:Figure 4).

\section{The Caddoan Ceramics}

\section{DL 239}

The ceramics provided by Paul Lorrain from 41DL239 include seven body sherds and one rim. A ninth sherd is reported, based on an illustration provided by Lorrain (Figure 1c), but it is not in the collection.

The five plain sherds (three body sherds, one body and base sherd, and one base sherd) have smoothed interior surfaces, and have grog $(n=2)$, grog and bone $(n=2)$ and grit $(n=1)$ temper inclusions; the grit aplastics have been finely crushed before being added to the clay paste. Body wall thickness ranges from $6.2-8.2 \mathrm{~mm}$, and the flat disk base sherds average $11.0 \pm 0.5 \mathrm{~mm}$ in thickness. Core colors suggest these sherds are from vessels that were either incompletely oxidized during firing or fired in a reducing environment, but then cooled in a high-oxygen environment (cf. Teltser 1993). 


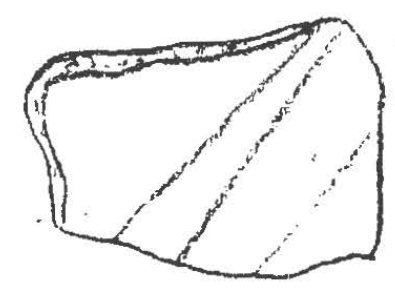

A

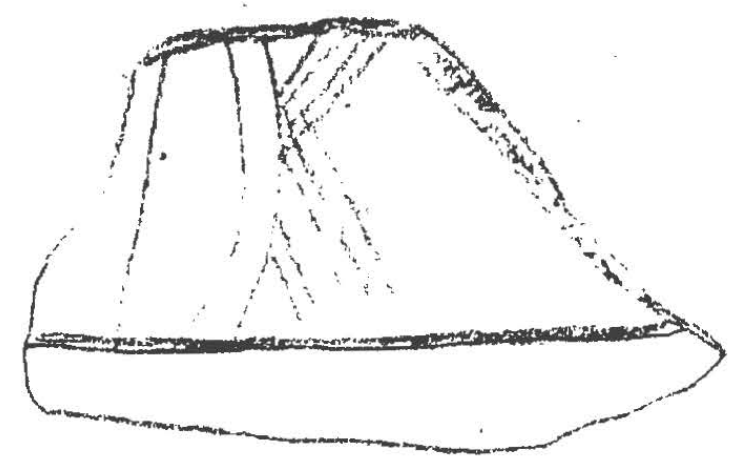

B

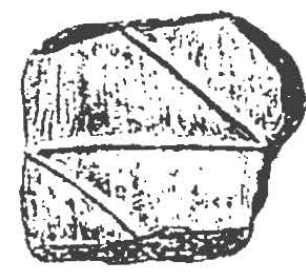

C

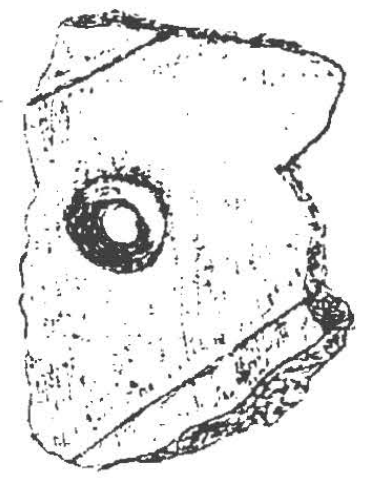

D

Figure 1. Decorated Ceramic Sherds from 41DL239. Scale is $1: 1$. 
Among the four decorated sherds from 41DL239 are three with incised lines and a fourth with diagonal and curvilinear engraved lines (see Figure 1). The incised sherds appear to be from jars, while the engraved piece is the lower rim and body of a carinated bowl (see Figure $1 \mathrm{~b})$.

The first incised sherd (see Figure 1a) has a parallel or diagonal decorative motif of finely drawn lines on the vessel body (and probably extending across the rim). The vessel has grog temper, and has been fired in an oxidizing environment. The second sherd (not in the collection I examined) appears to have a cross-hatched motif (see Figure 1c). The last incised sherd is a rim sherd with widely-spaced diagonal lines (see Figure 1d). It has grog and finely-crushed bone temper, and has been fired in a reducing environment. The rim is direct or standing, with a folded and rounded lip. The lip is scalloped, and there is a repair hole on the rim a few centimeters below the lip.

The engraved carinated bowl sherd (see Figure 1b) may be from a Poynor Engraved vessel (see Suhm and Jelks 1962:Plate 62; Kleinschmidt 1982:Figure 19). The decorative motif on the 41DL239 vessel sherd consists of part of a negative oval with cross-hatching; the cross-hatching apparently serves as a divider between two negative ovals (cf. Suhm and Jelks 1962:Plate 62a, c-e). The 41DL239 negative oval is bisected by a vertical line, which is not a common decorative element in this motif (see Kleinschmidt 1982:Figure 19, nos. $37,38)$.

\section{$41 \mathrm{DL} 240$}

There are 34 sherds in Paul Lorrain's 41 DL240 collection. 'Twenty-five sherds belong to Vessel 1 (described below), while the other nine are body, base, and rim sherds from an unknown number of separate vessels.

Among the miscellaneous nine sherds are two bases, six body sherds, and one rim. Both bases are flat discs, and are from vessels tempered with grog and bone and incompletely oxidized during firing. The bases range from 10.2-14.5 $\mathrm{mm}$ in thickness. The body sherds have been tempered with grog, and two also have either finely crushed bone or grit aplastics added to the paste. Only one of the sherds has been smoothed (on the exterior surface), and it also has a repair hole. Mean body wall thickness' for these sherds are $6.5 \pm$ $0.9 \mathrm{~mm}$, about the same thickness as the sherds from 41DL,239. These sherds are from vessels fired in both oxidizing $(n=3)$ and reducing $(n=3)$ environments. The rim sherd is direct with a flat lip, and has portions of a diagonal row of fingernail punctations on it. It is bone-tempered, $8.7 \mathrm{~mm}$ in thickness (probably from a large jar), and the vessel has been incompletely oxidized during firing.

Vessel 1 from 41 DL240 consists of 25 engraved sherds from a bowl of undetermined size with a rounded body and an everted rim (Figure 2a). The thin lip (3.8 $\mathrm{mm}$ ) has been rolled to the exterior and is also scalloped. It has finely crushed grog temper in a dense clay paste, and the vessel's very dark gray to black core indicates it has been fired in a reducing environment. Both the interior and exterior surfaces are brown to very dark gray in color, and they have been well burnished; small patches of polish are visible on the exterior surface. The vessel's wall thickness at the rim is $6.2 \mathrm{~mm}$, and it thickens to $6.7 \mathrm{~mm}$ on the upper body.

The engraved motif on Vessel 1 appears to consist of two related elements. The first is an engraved rectangle on the rim that has engraved semi-circles in each of the four comers (see Figure 2a, e); the semi-circles are defined by three increasingly larger engraved lines radiating out from the comers. From the sherds that are present, at least two engraved rectangles are present on the rim. The second engraved element is semi-circles pendant 

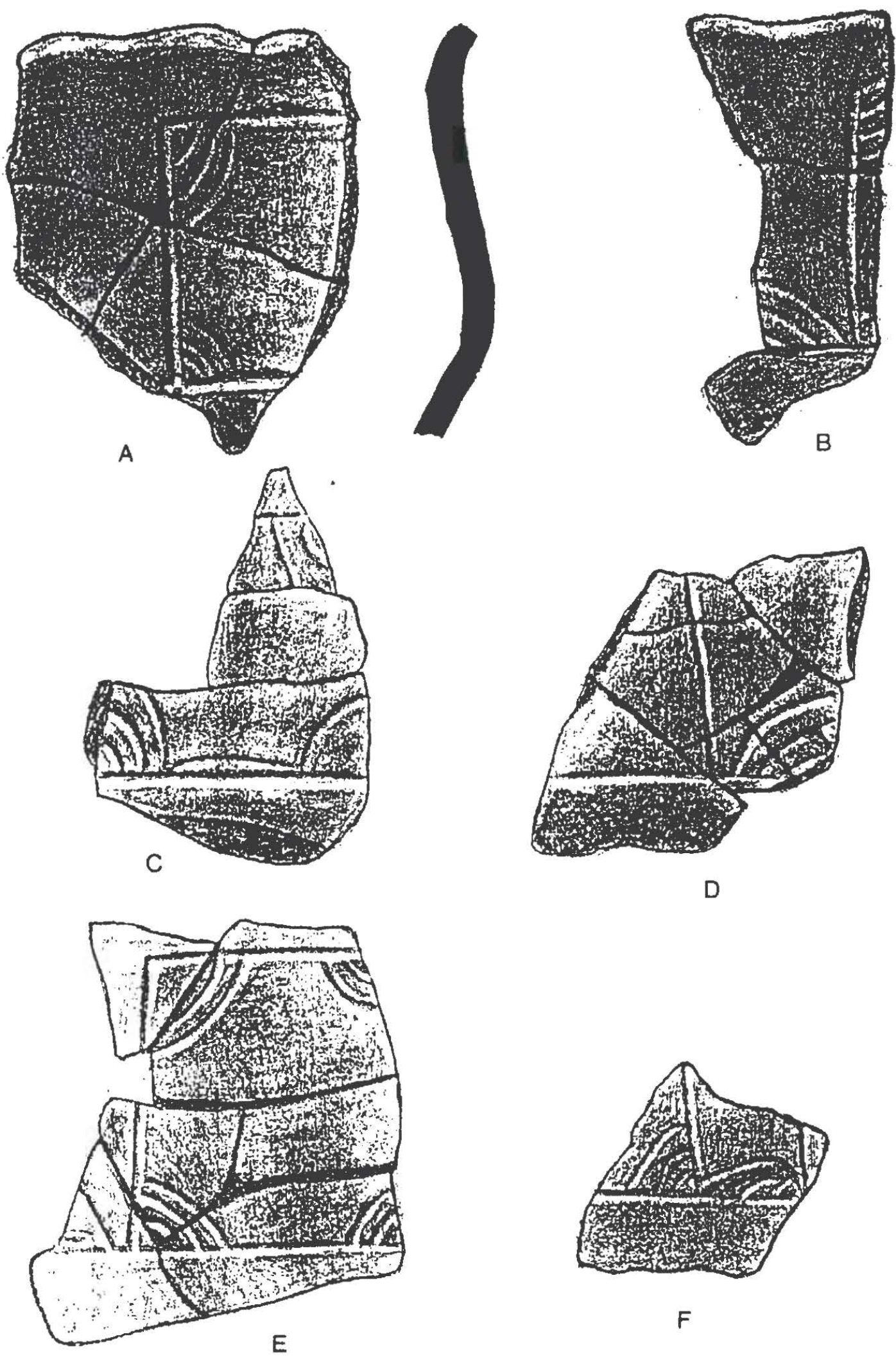

Figure 2. Rim and Body Sherd Sections from Vessel 1,41DL240. Scale is 1:1. 
from the engraved line that encircles the vessel at the bottom of the rim (see Figure $2 b, f$; this engraved line also forms the bottom half of the engraved rectangles (see Figure $2 a-b$, d). In one case, the semi-circle has been placed between two vertical lines or a panel (see Figure 2f), one of the lines forming part of the engraved rectangle itself.

The engraved motif on Vessel 1 does not appear to be from any of the currently defined engraved Caddoan ceramic types found in Northeast Texas. The shape of the vessel and rim are consistent with its being made in the Middle to Late Caddoan period, however.

The motif on Vessel 1 has broad similarities to several of the Poynor Engraved motifs and elements illustrated by Kleinschmidt (1982:Figure 19, nos. 22 and 50). The similarity lies in the use of a rectangle (or box) as the central element, but the semi-circles within the rectangle are a unique feature of the $41 \mathrm{DL} 240$ vessel. Interestingly, Gadus et al. (1997:Figure 37) illustrate a rim sherd from 41LN416 in the Trinity River drainage that is strikingly similar to a portion of the 41DL240 motif. The 4lLN416 sherd has an everted rim with a rounded lip, and on the rim is an engraved rectilinear panel (the sherd is not large enough to show the entire panel) with semi-circular to diagonal engraved lines at the corners of the panel. Gadus et al. (1997:72) conclude that "it is reminiscent of motifs associated with the type Poynor Engraved."

Ceramic vessels with engraved rectangles are also noted in Middle Caddoan period assemblages from the Sabine and Neches-Angelina river basins in Northeast Texas (see Hart 1982; Perttula 1998; see also Walters et al., this volume). The engraved rectangle motif is not common, however, being represented by single vessels at the Washington Square Mound and Redwine sites, and a handful of sherds from the Redwine and Oak Hill Village sites.

\section{Conclusions}

Caddoan pottery sherds from 41DL239 and 41DL240 on the Elm Fork of the Trinity River, well west of the Caddoan area in Northeast Texas, clearly document some form of contact between Caddoan peoples and the Native American inhabitants of the upper Trinity River basin. Engraved ceramics from these two sites appear to date to the Late Caddoan period (ca. A.D. 1400-1680), and share stylistic affiliations with Poynor Engraved ceramics made in the Neches-Angelina river basins during the Frankston phase. By contrast, previously reported Caddoan ceramics from the East Fork of the Trinity River and the Blackland Prairie, as well as the Elm Fork, are most notable in archaeological contexts predating A.D. 1300 (Perttula et al. 1995:190).

\section{Acknowledgments}

I would like to thank Paul Lorrain for loaning me the sherds from 41DL239 and 41DL240 for study, providing me a copy of his published article on 41DL239, and allowing me to use copies of his drawings of the decorated sherds in this article.

\section{References Cited}

Gadus, E. F., R. C. Fields, D. E. Williams, K. W. Kibler, and S. R. Sauer

1997 National Register Assessments of Prehistoric and Historic Sites in Area DX at the Jewett Mine, Freestone and Leon Counties, Texas. Reports of Investigations No. 112. Prewitt and Associates, Inc., Austin. 
Hart, J. P.

1982 An Analysis of the Aboriginal Ceramics from the Washington Square Mound Site, Nacogdoches County, Texas. M.A. thesis, Department of Anthropology, Northeast Louisiana University, Monroe.

Kleinschmidt, U. K. W.

1982 Review and Analysis of the A. C. Saunders Site, 41AN19, Anderson County, Texas. Master's thesis, Department of Anthropology, The University of Texas at Austin.

Lorrain, $\mathrm{P}$.

1978 Certain Sites in Northwestern Dallas County. The Record 34(1):9-10.

1985 Excavation at Site 2 on the Elm Fork. The Record 41(1):3-13. Dallas Archeological Society.

Perttula, T. K.

1998 The Decorated Ceramics from the Oak Hill Village Site (41RK214), Rusk County, Texas. MS on file, Espey, Huston \& Associates, Inc., Austin.

Perttula, T. K., M. R. Miller, R. A. Ricklis, D. J. Prikryl, and C. Lintz

1995 Prehistoric and Historic Aboriginal Ceramics in Texas. Bulletin of the Texas Archeological Society 66:175-235.

Prikryl, D. J.

1990 Lower Elm Fork Prehistory: A Redefinition of Cultural Concepts and Chronologies along the Trinity River, North-Central Texas. Office of the State Archeologist Report 37. Texas Historical Commission, Austin.

Suhm, D. A. and E. B. Jelks (editors)

1962 Handbook of Texas Archeology: Type Descriptions. Special Publication No. 1, Texas Archeological Society, and Bulletin No. 4, Texas Memorial Museum, Austin.

'Teltser, P. A.

1993 An Analytic Strategy for Studying Assemblage-Scale Ceramic Variation: A Case Study from Southeast Missouri. American Antiquity 58(3):530-543. 